\title{
Fenomenología
}

\section{Ethic and bioethic dilemmas on palliative care for hospitalized elderly: nurses' experience.}

\section{Dilemas éticos y bioéticos en los cuidados paliativos de mayores hospita- lizados: vivencia de enfermeras}

\section{Dilemas éticos e bioéticos nos cuidados paliativos de pessoas idoas hospitalizadas: vivencia de enfermeras}

Juliana Bezerra do Amaral' ${ }^{1}$, Maria do Rosário de Menezes², Maria Antonia Martorell-Poveda ${ }^{3}$,

Simone Cardoso Passos 4 .

${ }^{1}$ RDoctoranda en Enfermería - Programa de Pós-graduação em Enfermagem da Universidade Federal da Bahia. (Brasil). Bolsista de la Fundación Carolina en la Universidad Rovira i Virgili, Tarragona (España). Profesora Assistente de la Escola Bahiana de Medicina e Saúde Pública, Salvador - Bahia (Brasil).

${ }^{2}$ Profesora adjunta nível 3 de la Escola de Enfermagem da Universidade Federal da Bahia, Departamento de Enfermagem Médico Cirúrgica e Administração de Enfermagem, Salvador-Bahia (Brasil).

${ }^{3}$ Profesora Titular, Departamento de Enfermería, Universidad Rovira i Virgili, Tarragona (España).

${ }^{4}$ Maestra en Enfermería - Programa de Pós-graduação em Enfermagem da Universidade Federal da Bahia. Salvador - Bahia

(Brasil). Profesora Assistente de la Escola Bahiana de Medicina e Saúde Pública. Salvador - Bahia (Brasil).

Cómo citar este artículo en edición digital: Bezerra do Amaral J; Menezes Mar; Martorell-Poveda Ma A; Cardoso Passos S. (2012) Ethic and bioethic dilemmas on palliative care for hospitalized elderly: nurses' experience. Cultura de los Cuidados. (Edición digital) 16, 33. Disponible en: <http://dx.doi.org/10.7184/cuid.2012.33.02>

Correspondencia: Juliana Bezerra do Amaral. Avenida General Severino Filho, $n^{\circ}$ 1029, Condomínio Aldeiotta, 16C, Itapuã CEP: 41.600-096. Correo eletronico: julianabamaral@yahoo.com.br Recibido: 21/11/2011/ Aceptado: 13/4/2012

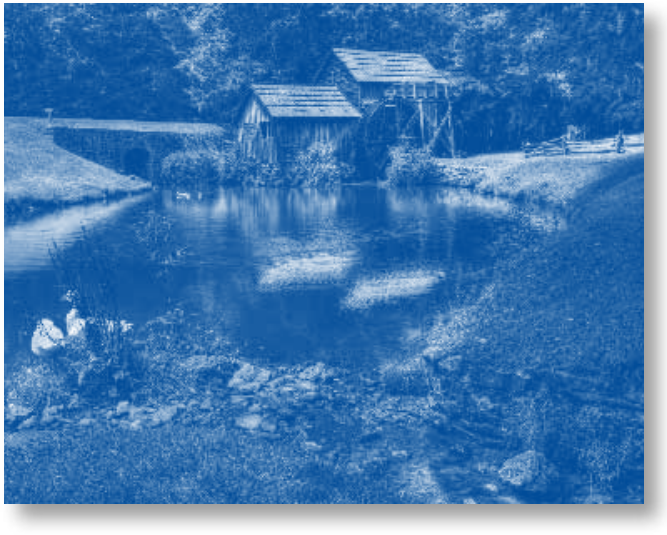

RESUMEN

Objetivo: analizar los dilemas éticos y bioéticos vivenciados por enfermeras que ofrecen cuidados paliativos a mayores hospitalizados en una unidad de cuidados paliativos geriatrica de la ciudad de Salvador - Brasil, de mayo a agosto de 2005.

Metodología: Estudio cualitativo, exploratorio, descriptivo. Para la recogida de datos se utilizó la entrevista y la historia oral temática. Los datos fueron sometidos al análisis de contenido.

Resultados: del discurso surgieron dilemas como: Prolongando artificialmente la vida; Alimentando pacientes en condiciones terminales; Negando informaciones; y obteniendo un efecto indeseado - doble efecto.

Conclusión: Las enfermeras vivencian algunos dilemas éticos y bioéticos, conflictos de valores y contradicciones, pues es imposible dissociar los aspectos históricos y culturales 
del cotidiano de los profesionales de salud. Sin embargo, la profundización teórica sobre la temática contribuirá para la plena implantación de los cuidados paliativos, promoviendo una transformación de la visión cultural sobre el proceso de muerte y morir.

Palabras clave: enfermería, cuidados paliativos, mayores, bioética.

\section{RESUMO}

Objetivo: Analisar os dilemas éticos e bioéticos vivenciados por enfermeiros que prestam cuidados paliativos a idosos internados em uma unidade geriátrica de cuidados paliativos da cidade de Salvador - Brasil, no período de maio a agosto de 2005.

Metodologia: estudo qualitativo, exploratório e descritivo. Para a coleta de dados foi utilizado entrevista temática da história oral. Os dados foram submetidos à análise de conteúdo.

Resultados: dos discursos emergiram dilemas, como: prolongando a vida artificialmente; alimentando pacientes em condições terminais, negando informações, e obtendo um efeito indesejado - duplo efeito.

Conclusão: As enfermeiras vivenciam dilemas éticos e bioéticos, conflitos de valores e contradições, pois é impossível dissociar os aspectos históricos e culturais do cotidiano dos profissionais de saúde. No entanto, o estudo teórico sobre o assunto irá contribuir para a plena implementação dos cuidados paliativos, promovendo uma transformação cultural da visão cultural sobre o processo de morte e morrer.

Palabras chaves: enfermera, cuidados paliativos, idosos, bioética.

\section{ABSTRACT}

Objective: analyzing ethic and bioethics dilemmas experienced by nurses who take palliative care for hospitalized elderly.

Method: quality study, exploring, descriptive, using the interview as technical for collecting oral history from tem nurses. The context was a geriatric palliative care unit from the city of Salvador - Brazil, in the period between May and August 2005. Content was used for speech analyzing.

Results: the speeches arose dilemmas like: artificially prolonging of life; feeding terminal condition patients; neglecting information; and obtaining an undesired effect - Double effect.

Conclusion: the nurses experienced some ethic and bioethics dilemmas, values conflicts and contradictions, for it is impossible to dissociate the historical and cultural aspects inserted in the daily life of the Health Professionals. However, the theoretical study about this theme Will contribute to complete deployment of the basics of palliative care by enabling cultural point of view transformation concerning to the process of dying and death.

Keywords: nursing, palliative care, elderly, bioethics.

\section{INTRODUCTION}

Medicine and nursing are sciences in constant renovation due to the advances in the investigation of diseases, development of new therapies, improvement in technical measures for diagnosis which lead to the discovery and treatment of many problems, promoting, this way, a great benefit to humanity by collaborating with the increase in life expectancy and improvement in the health situation of the population. 


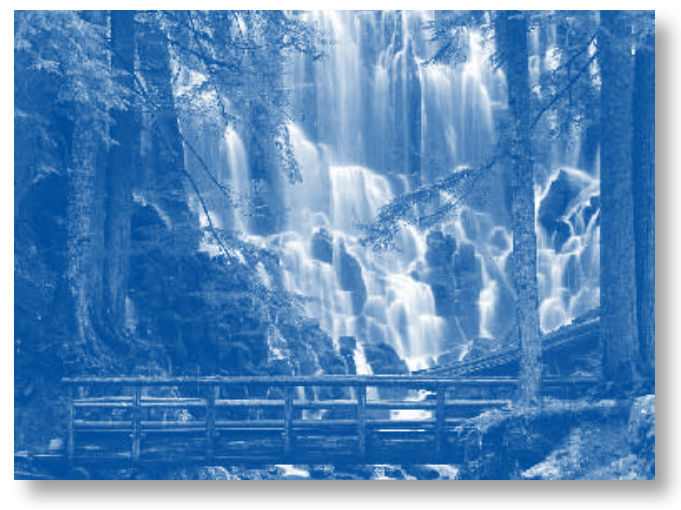

Nevertheless, progress does not always have the same meaning for the elderly who present non-transmissible and incurable diseases, since most of them are condemned to live with intense suffering and abandonment (Villamizar, 1992). Without granting them the benefits of hard technology, but offering the light form of treatment centered in the reception, attentive listening, and in the promotion of comfort and affection.

The western culture, based on the biological model of health and illness, hospital-centered care, often favors suffering and abandonment faced by many of the elderly with incurable diseases, since life is understood as being the greatest benefit and it is the responsibility of the medical professional to maintain life, even when life is prolonged through artificial means.

There is no doubt that technologies will totally change the ways of living and dying. However, it must be acknowledged that it is not possible to avoid death. It is possible to delay, but not avoid death (Gracia, 2005). Once this is the unchangeable destiny of all living creatures, death and the process of dying, as well as the quality of living, should be thought and discussed openly in all spaces of health area as well as in educational and health care institutions, since there are feelings that accompany the process of death, such as pain, fear, frustra- tion, inequity, sadness, loneliness, among others (Vega and Juan, 2011; Gonçales, 1999).

Therefore, with the purpose of changing healthcare towards patients with incurable and progressive diseases, the principles and philosophies of palliative care with the purpose of identifying, evaluating and controlling symptoms resurge, considering the physical, social, physiological and spiritual dimensions of the person to be cared for, providing quality to the death process of the patient as well as support to the family (Pessini, 2004).

Nonetheless, despite the strengthening of debates raised by the philosophy of palliative care, which favors comparison with the patient, families and health professional, the latter faces ethical and moral dilemmas for decision making when caring for patients with non-transmissible and progressive illnesses due to the prevailing culture and biomedical model.

In this perspective, this article, product of a masters dissertation by one of the authors, entitled "The meaning of health care/palliative care for hospitalized elderly: oral accounts of nurses", has the purpose of discussing ethical and bioethical dilemmas faced by nurses in the palliative care of hospitalized elderly patients, confirming the permanent necessity of the discussion within our professional environment.

\section{METHODOLOGY}

This paper is of explanatory-descriptive nature with a qualitative approach in the analysis of the information. The context was a palliative health care unit in a Geriatric Center in the city of Salvador-Bahia, in the period of May to August, 2005.

The thematic oral accounts were used on the basis that the true story is investigated from those who experienced a certain event 
or who at least have a version that is debatable (Meihy, 1998). Therefore, though semi-structured interviews of 10 nurses were collected in the age group between 25 and 45 years, who had experienced palliative care of hospitalized elderly patients.

The stipulations of the National Ethics Commission in Investigation observing the ethical aspects of Resolution 196/96 of the National Health Council were complied (National Health Council, 1997). The performance of the investigation was approved by the Ethics Committee of the Santo Antonio Hospital, registered under number 021 on March 28, 2005.

The interviews were previously established, in accordance with the availability of the collaborators, and recorded in a recorder after the clarification of the confidentiality and anonymity of the interviews and the possesson of a written authorization, permitting the recording and use of the information after transcription and contextualization.

To assist in the analysis of the narratives of the interviewed parties the Bardin content analysis was used, being "indicated in the study of motivations, attitudes, values, beliefs, tendencies" (Leopardi, 1999).

\section{RESULTS AND DISCUSSION}

From the accounts of the nurses four categories arose relating to ethical and bio-ethical dilemmas experienced on caring for the elderly hospitalized for palliative care. These were coded as: 1) Prolonging life - dysthanasia; 2) Feeding patients in terminal conditions; 3) Denial of information - autonomy and 4) Obtaining an undesired effect - double effect.

\section{1) Prolonging life artificially - dysthanasia}

Seemingly, in the testimony of some of the interviewed parties, the reality of artificial prolongation of life drives us to reflect on the necessity of palliative care in our society. For example, one of the nurses commented:

(...) every one of them can be reanimated, so I do not make any distinction (...). Look! During my shift, the patient does not go into cardiac arrest, because before even imagining that he may, I will take all nursing (...) actions (....). Ent. 9.

These words illustrate the behavior of some professionals in the face of the inevitability of death of people in the final phases of illness, causing great suffering to these by taking unnecessary measures which do not grant the patients their human dignity. To talk about this behavior we use the term Dysthanasia, which refers to a painful death and which is the antonym of Euthanasia, which is defined as a practice in which the life of a patient, with a recognizably incurable disease, is abbreviated without pain or suffering (Bueno Silveira, 1980).

Ortotanasia is defined as death on its own time, without any disproportional abbreviation or prolongation of the process of death. The name ortotanasia comes from the Greek "orthos" (upstanding, correct) and "thanatos", which denotes death (Pessini, 2001). The practice of ortotanasia tends to avoid dysthanasia.

Nevertheless, despite the possibly unconscious conduct of the professional faced with the process of death of patients, in their accounts it was possible to identify the understanding of the meaning of palliative care as a comfort care, as demonstrated below:

(...) to me, palliative care would be the comfort of the patient where nurses can perform their complete activities (...), she also contradicts herself by informing that "during my turn (work shift), the patient does not go (cardio-respiratory arrest), because before imagining that 
the patient will go (....) I will take all the nursing actions and, after that, he may go (die), but in another shift, not in mine, so as no-one can say, ah! (...) confirmed". Ent. 9.

One can infer, from a bioethical point of view, there was an infringement of the nonmalfeasance, one of the principles of the ethics trinity which implies in not causing unnecessary damage or suffering to patients throughout the treatment given, which is the obligation of the health professionals.

One should recollect also that in Chapter V, article 46, of the Nursing Professionals' Code of Ethics, there is a guidance against euthanasia and dysthanasia, prohibiting professionals of "promoting euthanasia or cooperating in practices leading to the anticipation of the client $\backslash$ s death" (Federal Council of Nursing, 2004)

In a study about dying with dignity the author reflects that the presence of a routine in which there are various duties and a lot of responsibility, nursing professionals associate that the correct attitude is not to let the patient die (Esslinger, 2003).

Hence, the assertions of the collaborating nurse reflects her desire to maintain life, not performing actions that would be characterized as dysthanasia, because the team of this Geriatric Center has been offering to its professionals study groups about palliative care and awareness workshops for caring for the terminally ill elderly.

\section{2) Feeding patients in terminal conditions}

Food and beverages consumed in a community are an essential part of the culture, apart from being related to a means of subsistence and to an agreeable experience, also collaborate towards promoting comfort, communication and social interaction. Neverthe- less, despite exercising one of the main roles in peoples' lives, which does not change as time passes or in the presence of a serious illness, when the latter occurs, food is marked by its absence or by the difficulties of ingestion (Esslinger, 2003).

Nurses working in palliative care often present loss of weight or anorexia due to multiple causes. Anguish is caused to family members and caretakers due to the absence of food which will not alter the course of the illness (Esslinger, 2003). From the words of one of the nurses interviewed, the difficulty of the professionals emerges in relation to accepting the denial of nutritional support by the elderly, despite their technical-scientific knowledge revealed in the accounts.

Time goes by and the patient does not wish to eat, but I tell the patient, you will go without eating. According to the literature, if the patient does not wish to eat, one must not give them food. I ask myself: "Will they die of hunger?" (...) It is necessary to mature this idea of palliative care. Ent. 7.

The traditional opinion in the hospices is that "when a patient no longer wishes to be fed, the patient should not be forced" (Pessini, 2004). And, that in the "last days of life, the metabolism is altered and the energy used for digestion, even when in small quantities, is very difficult for the patients", because the acetonemia (abnormal increase of ketone bodies in the blood) present at the final moments of life, offering, among other things, relief to pain. In this manner, the forced diet therapy could lead to prolonged suffering to patients (Pinto, 2009).

While nutritional support through artificial feeding (enteral or parenteral) in the context of the terminal situation, many complications can occur due to the central venous 
catheters and enteric tubes, such as: infections, pneumothorax, nausea, gastric ecstasia, abdominal extension, diarrhea, among others (Pinto, 2009).

Therefore, considering that the continued refresher courses performed with professionals of services for healthcare of patients in palliative care could lead to a modification in the culture that it is necessary to keep feeding these patients, when the loss of appetite and cachexia of the ill are due to the progression of the illness.

\section{3) Denial of information - autonomy}

This category was thus denominated because nurses revealed that they do not issue and do not accept to inform patients on their state of health and closeness of death.

According to Chapter IV, articles 26 and 30, of the Nursing Professionals' Code of Ethics it is informed that it is the duty of the professionals to "render adequate information to the client and family members in relation to the nurse-care, possible benefits, risks and consequences which could occur, as well as collaborating with the health team in clarifying to the client and family members about the state of health and treatment, possible benefits, risks and consequences which could occur" (Federal Council of Nursing, 2004).

Hence, the patient and family members should receive clear, objective and comprehensible information, adapted to their cultural condition, on the actions, diagnosis and therapies, whereby the patient has the right to consent or refuse the procedures to be performed.

The patient does not need to know that hel she has a terminal illness, does not need to know that he/she has only a few days to live, does not need to know that there is no cure for his/her illness, does not need to know any of this. Ent. 7.
It is true [pause], patients, I believe, should not be informed about their clinical symptoms, (...) they do not have the knowledge, although maybe they do have an idea, (....)., (...). Since they are wise people, I believe they are aware of when they are close to dying. Ent. 10.

This situation of not informing the patients about their state of health, apart from violating the principle of autonomy, recognized as the principle of right and will of the persons governing themselves, it can also be related to cultural and paternalist attitudes, characteristic of Latin American countries, protecting their patients. In Anglo-Saxon countries, on the other hand, objectivity of information is valued and performed by the professionals (Pessini, 2004).

Nonetheless, in extreme situations, when there are fair reasons for imagining that the truth is incompatible with respect to human dignity, the breach of truth can be conceived (Gracia, 2005). Working with the elderly in terminal conditions, for example, makes possible to identify situations in which the principle of autonomy may be totally or partially disregarded, since there are patients that suffer from neuropsychiatric disorders which make comprehension of the information difficult, as in the case of dementia, and others are abandoned by their families and dear ones in institutions, impeding that they, as legal responsible, have any right to know or decide.

However, no matter how difficult communication of the truth is in this situation, the principle of veracity should always be respected, because this is the basis of trust in interpersonal relationships, because it benefits the elderly and the family (principle of beneficence) permitting participation in decision making (autonomy) (Pessini, 2004). 


\section{4) Obtaining an undesirable effect - double effect}

The principle of the double effect is characterized as an action of care which when performed entails in negative effects to the patient. A common event in palliative care occurs when there is the necessity of analgesia and sedation for patients in intense pain, as difficulty in breathing, anxiety, agitation and acute confusion and, after the administration of drugs such as morphine, which can produce effects such as a decrease in blood pressure or respiratory depression, the patient deceases. This is an example of an undesired effect.

This situation is evidenced in the following comment, in which the nurse emphasizes that the main objective was to alleviate suffering and promote quality of life, where accompaniment was offered to the patient.

There was one patient who was in a lot of pain and had morphine prescribed in case necessary. Therefore morphine was administered, and the patient went (...), the blood pressure was inaudible, and slowly the elderly patient deceased, but we were giving all the due assistance, knowing that these were palliative care, all of us were accompanying, giving all the assistance. Ent. 3

So, the double effect principle occurs when a therapy represents the best possible (good action), used with the direct purpose of causing a positive effect, and its consequences (collateral effect) can lead to negative situations (Pessini, 2004).

Finally, it is understood that adequately structured palliative care, with guidelines established for difficult decision making, is of fundamental importance to elderly patients in terminal conditions, because it "does not avoid euthanasia, but decreases appreciably the request for euthanasia” (Gracia, 2005).

\section{FINAL CONSIDERATIONS}

The results obtained and presented permit the affirmation that nurses are still in full construction of the comprehension of nursing assistance/care in terminal process of hospitalized elderly patients. Consequently, some ethical and bioethical dilemmas, conflicts of values and contradictions are identified in the comments of the interviewed nurses in the practice of nurse-care to patients with nontransmittable and incurable diseases, because it is impossible to disassociate the historical and cultural aspects in the daily lives of health professionals.

It is considered that the influence of the curative formation is still strongly linked to the difficulties found for the credible comprehension of the principles and philosophies of palliative care, a reality which is already consolidated in European countries and originated from the modern hospice movements.

Lastly, palliative care renders attention during the final moments of the patients' lives, because its philosophy proposes an integral vision of the individual in the presence of an incurable pathology and in all the derived circumstances, and the professionals put forth debates about terminal sedation, analgesic therapy, feeding, blood transfusions and reanimation.

In this context, health professional should become aware of the bioethical principles that fundament and accompany the professional practice, in a process of continuous reflection and ample discussion about health and the specificity of each service (Germano, 1993). 


\section{BIBLIOGRAPHY}

- Bueno Silveira, F. (1980) Dicionário escolar da língua portuguesa. 11. Ed.. Rio de Janeiro: FENAME.

- Carvalho, R; Taquemori, L. (2008) Nutrição e Hidratação in: OLIVEIRA AYER, R. et al(col) Cuidados Paliativos. São Paulo: Conselho Regional de Medicina do Estado de São Paulo.

\section{- CONSELHO FEDERAL DE ENFERMAGEM (2004) IV} do Código de Ética dos Profissionais de Enfermagem [diponible en: http://www.coren-rj.org.br/codigo_etica.htm ] (consultado en mayo de 2005).

\section{- CONSELHO NACIONAL DE SAÚDE (1997). Resolução} CNF nº. 196, de 10 out. Resolve aprovar diretrizes e normas regulamentadoras de pesquisas envolvendo seres humanos. Brasilia, Brasil.

- Esslinger, I. (2003) O paciente, a equipe de saúde e o cuidador: de quem é a vida afinal? Um estudo acerca do morrer com dignidade. São Paulo, Tese (Doutorado em Psicologia) - Instituto de Psicologia, Universidade de São Paulo. São Paulo, 397 p.

- Germano, R. (1993) A ética e o ensino de ética na enfermagem do Brasil. São Paulo: Cortez;. 73-78.

- Gonçalves, LHS. (1999) Aprendendo a cuidar de pessoas em condição terminal. In: Py, P (org). Finitude: uma proposta para reflexão e prática em gerontologia. Rio de Janeiro: NAU.
- Gracia, D. (2005) Uma reflexão sobre a autonomia contemporânea em relação à morte. Revista IHU On-Line. 8-11 [disponible en: http://www.saofrancisco.edu.br/ itatiba/uploadAddress/Eutanasia_entrevistas[9495].pdf] (consultado en noviembre de 2005)

- Leopardi, M. (1999) Teorias em enfermagem: instrumentos para a prática. Florianópolis (SC): Papalivros.

- Meihy, J. (1998) Manual de história oral. 20. ed. São Paulo (SP): Loyola, 86pp.

- Pessini, L. (2004) A filosofia dos cuidados paliativos: uma resposta diante da obstinação terapêutica. In: PESSINI, L.; BERTACHINI, L. (Org.). Humanização e cuidados paliativos. São Paulo: Loyola.

- Pessini, L. (2001) Distanásia: até quando prolongar a Vida? São Paulo: Centro Universitário São Camilo.

- Pinto, C. (2009) Procedimentos sustentadores de vida em Cuidados Paliativos: uma questão técnica e bioética. En: Manual de cuidados paliativos / Academia Nacional de Cuidados Paliativos. Rio de Janeiro: Diagraphic, 195-201

- Vega, M.. Juan, L. (2011) Perspectiva de la enfermera ante el paciente oncológico en fase terminal en Tampico, Tamaulipas, México. [disponible en: http://www.index-f. com/cultura/30pdf/30-052.pdf]

- Villamizar, E. (1992) Sintomas Gastrointestinais. En: Bejarano, P.F.; Jaramillo, I. Morrir com dignidad - fundamentos del cuidado paliativo - atención interdisciplinaria del paciente terminal. Colombia: Amazonas Editores.

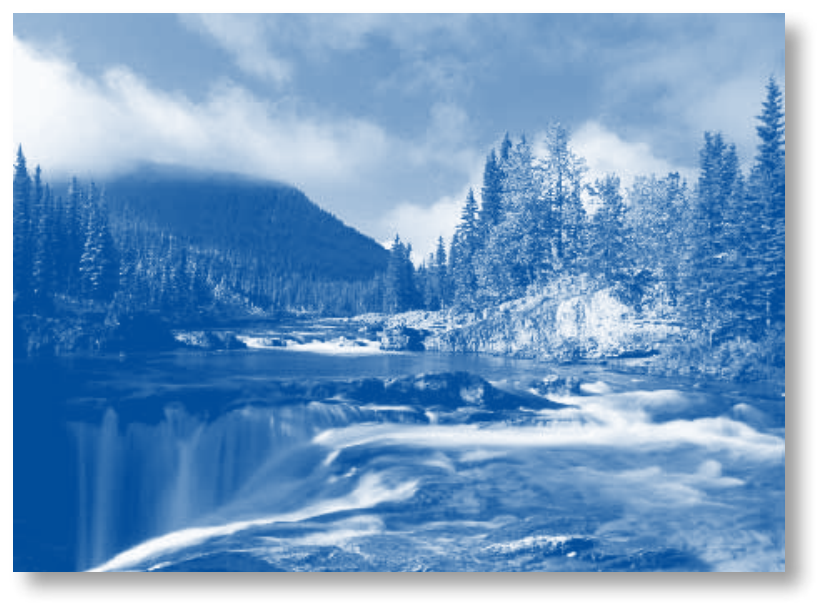

